\title{
Faktor Kerentanan Food Fraud dan Mitigasinya : Studi Kasus Pada Produsen Susu Bubuk di Indonesia
}

\author{
Vulnerability Factors of Food Fraud and Its Mitigation : Case Studies at Powdered Milk Producers in \\ Indonesia
}

\author{
A. Fitrawanti ${ }^{1}$, R. Dewanti-Hariyadi ${ }^{2,3^{*}}, \&$ N. Wulandari ${ }^{2,3}$ \\ ${ }^{1}$ Program Magister Teknologi Pangan, Departemen Ilmu dan Teknologi Pangan, Fakultas Teknologi Pangan, \\ IPB University \\ ${ }^{2}$ Departemen Ilmu dan Teknologi Pangan, Fakultas Teknologi Pangan, IPB University \\ ${ }^{3}$ Southeast Asean Food and Agricultural Science and Technology (SEAFAST) Center, IPB University \\ Kampus IPB Darmaga Bogor, PO Box 220 Bogor, Indonesia \\ *Corresponding author: ratihde@apps.ipb.ac.id_ \\ (Received 29-01-2021; Revised 24-02-2021; Accepted 20-03-2021)
}

\begin{abstract}
Food fraud is one of the risks in the supply chain globalization. A complex and long supply chain with different locations, cultures, business ethics, policies and surveillance systems are the contributing factors to food fraud. This study aims to identify food fraud vulnerability factors in milk powder producers. It was conducted in two companies which uses powder and liquid milk as the raw materials which is typical in Indonesian powdered milk industry. The study steps consist of respondents determination, data collection and analysis, formulating mitigation strategies. The respondents were company's head of departments and a government officer of the National Agency for Drug and Food. Data collection and analysis were carried out with the Safe Supply Affordable Food Everywhere (SSAFE) tool, while mitigation strategies was formulated through Focus Group Discussion. The results show that vulnerability to food fraud rooted from the opportunity factor, namely the easiness and availability of technology to commit fraud, motivational factor namely the level of corruption and regulatory differences that affect prices, control measures factors due to lack of supervision, employee integrity tests and prevention guidelines. Internally improving control measures within the company and guideline prevention from the government were mitigation measures to be done.
\end{abstract}

Keywords: food fraud, milk powder, mitigation, SSAFE,vulnerability

\section{ABSTRAK}

Food fraud atau kecurangan pangan untuk memperoleh keuntungan ekonomi adalah salah satu risiko yang perlu diwaspadai pada globalisasi rantai pasok. Rantai pasok bahan baku yang panjang, kompleks dengan perbedaan lokasi geografis, budaya, etika berbisnis, kebijakan negara dan sistem pengawasan merupakan faktor penyebab kerentanan terhadap food fraud. Penelitian ini bertujuan mengidentifikasi faktor kerentanan food fraud pada produsen susu bubuk dengan bahan baku bubuk susu dan susu cair yang lazim digunakan oleh industri susu di Indonesia. Penelitian dilakukan dengan tahapan penentuan responden, pengumpulan dan analisis data, penyusunan strategi mitigasi. Responden adalah pimpinan departemen di perusahaan dan Badan Pengawas Obat dan Makanan. Pengumpulan dan analisis data dilakukan dengan piranti Safe Supply Affordable Food Everywhere (SSAFE) sedangkan strategi mitigasi dilakukan dengan diskusi terfokus. Hasil penelitian menunjukkan, kerentanan food fraud pada faktor kesempatan yaitu jenis bahan baku dan keberadaan teknologi untuk melakukan kecurangan, pada faktor motivasi yaitu tingkat korupsi negara dan perbedaan regulasi antar negara yang mempengaruhi harga, serta pada faktor sistem pengawasan yaitu kurangnya sistem pengawasan pada bahan baku, belum adanya uji integritas karyawan dan pedoman pencegahan food fraud. Perbaikan sistem pengawasan di perusahaan dan pedoman dari pemerintah merupakan upaya mitigasi yang harus dilakukan untuk mencegah food fraud.

Kata kunci: kecurangan pangan, kerentanan, mitigasi, SSAFE, susu bubuk 


\section{PENDAHULUAN}

Kebutuhan bahan baku susu oleh industri susu bubuk di Indonesia mencapai 3.3 juta ton/tahun dan sekitar 2.61 juta ton (79.02\%) diimpor dari Selandia Baru, Australia, Amerika Serikat dan negara kawasan Uni Eropa (Pusdatin 2018). Hal ini karena pasokan dalam negeri tidak mencukupi kebutuhan industri. Impor bahan baku susu berupa susu skim, whole milk powder dan butter milk powder. Bubuk susu impor memiliki rantai pasok panjang dan kompleks karena letak geografis pemasok dan pengguna yang berbeda dan melibatkan berbagai pihak selama distribusi.

Salah satu risiko yang perlu diwaspadai pada globalisasi rantai pasok pangan adalah food fraud, yaitu kecurangan pangan yang sengaja dilakukan untuk memperoleh keuntungan ekonomi (Spink \& Moyer 2011; Johnson 2014; GFSI 2014) yang mencakup penggantian bahan, penambahan, perusakan produk, pemberian informasi produk yang salah di kemasan dan label produk pangan (GFSI 2014). Food fraud berisiko terhadap keamanan pangan (Everstine et al. 2013) dan menimbulkan konsekuensi lainnya yaitu kerugian keuangan, rusaknya reputasi perusahaan dan reputasi sistem pengawasan negara dan asosiasi industri (Yang et al. 2019).

Insiden food fraud pada produk susu dilaporkan terjadi di Tiongkok, Brazil dan India (Yang et al. 2019; Tibola et al. 2018), dengan kasus terbesar adalah penambahan melamin pada susu formula bayi di Tiongkok tahun 2008 yang menyebabkan kematian pada 6 bayi (Fung et al. 2018). Oleh karena itu, food fraud perlu mendapat perhatian oleh pelaku industri susu di Indonesia.

SSAFE (2015) mengusulkan tiga faktor yang menyebabkan kerentanan terhadap food fraud yaitu faktor kesempatan, motivasi dan sistem pengawasan. Faktor kesempatan berkaitan dengan waktu, tempat dan kemudahan melakukan food fraud pada bahan baku maupun produk. Faktor motivasi disebabkan oleh alasan ekonomi, budaya, etika berbisnis dan strategi bisnis (Ruth et al. 2017). Faktor pengawasan berkaitan dengan tersedianya sistem pengendalian terhadap food fraud di tingkat produsen maupun oleh pemerintah.

Pemerintah melalui Permentan Nomor 33 tahun 2018 mendorong kemitraan pelaku industri susu dan peternak lokal untuk meningkatkan penggunaan susu segar dalam negeri. Daud et al. (2015) menyatakan pada rantai pasok susu segar di Indonesia terdapat risiko kualitas bahan baku yang disebabkan karena kualitas ternak, bahan pakan, praktik penanganan susu di peternak dan koperasi pengumpul susu serta sistem transportasi yang kurang memadai. Hal ini diidentifikasi sebagai faktor kerentanan food fraud di bahan baku susu cair.

Berdasarkan fakta diatas, rantai pasok bahan baku industri susu di Indonesia menjadi lebih kompleks dan memerlukan kajian kerentanan food fraud. Penelitian dilakukan melalui kajian internal untuk mengidentifikasi faktor penyebab kerentanan dan upaya mitigasi food fraud yang bermanfaat untuk meningkatkan jaminan keamanan pangan di produsen susu bubuk. Produsen merupakan perusahaan yang memiliki volume penjualan 54\% dari total volume pasar di Indonesia tahun 2019 (Market Research 2019).

\section{MATERI DAN METODE}

Penelitian dilakukan di dua perusahaan yaitu PT X dan PT Y yang berlokasi di Jawa Tengah dan DKI Jakarta. Kegiatan bisnis perusahaan meliputi penerimaan bahan baku, proses produksi dan pemasaran produk ke distributor yang merupakan rantai pasok tipikal industri susu di Indonesia. PT X menggunakan bahan baku bubuk susu impor dan susu cair lokal, sementara PT Y hanya menggunakan bahan baku bubuk susu impor.

\section{Materi}

Materi yang digunakan di penelitian ini adalah kuesioner SSAFE (2020) dan satu pertanyaan terbuka untuk mengidentifikasi faktor lokal spesifik food fraud.

\section{Metode}

Penelitian dibagi menjadi tiga tahap yaitu (1) penentuan responden, (2) pengumpulan dan analisis data dan (3) penyusunan strategi mitigasi.

Penentuan responden. Responden penelitian terdiri dari pimpinan departemen di perusahaan, Kepala Seksi Inspeksi Badan Pengawas Obat dan Makanan (BPOM). Pimpinan departemen di perusahaan dipilih sebagai responden karena bertanggung jawab langsung pada proses bisnis di departemen tersebut. Tema kuesioner SSAFE (2020) dan respondennya dijabarkan pada Tabel 1 .

Pengumpulan dan analisis data. Pengumpulan data dilakukan dengan wawancara responden. Materi kuesioner SSAFE (2020) diberikan sebelum wawancara. Setiap pertanyan pada kuesioner memiliki satu jawaban akhir (skor) yang dipilih berdasarkan kriteria yang ada di dalam kuesioner. Pada akhir wawancara, diajukan satu pertanyaan terbuka ke semua responden untuk mengidentifikasi faktor lokal kerentanan food fraud. Analisis data dilakukan dengan dua tahap yaitu tahap analisa pemetaan gabungan dan tahap identifikasi faktor kerentanan lokal. Analisa pemetaan gabungan dilakukan untuk mengidentifikasi faktor utama kerentanan food fraud. Penghitungan menggunakan rumus berikut (Yang et al. 2019):

$$
F(i)=\frac{1}{3} \sum\left(\ldots: \frac{X i j}{n j}\right)
$$

$F(i)$ adalah frekuensi dari skor $(1,2,3)$ pada setiap pertanyaan, $x_{i j}$ adalah jumlah pengamatan yang mendapatkan skor (i) pada kedua perusahaan, nj adalah jumlah total observasi / perusahaan. Frekuensi skor dengan nilai yang tertinggi digunakan sebagai skor akhir pada setiap pertanyaan di pemetaan gabungan. Pada faktor kesempatan dan motivasi, skor 1 menunjukkan kerentanan rendah terhadap food fraud, skor 2 menunjukkan kerentanan sedang dan skor 3 menunjukkan kerentanan tinggi. Hal ini berlaku sebaliknya pada pertanyaan di faktor sistem pengawasan. Skor 1 menunjukkan kerentanan tinggi terhadap food fraud karena sistem pengawasan yang lemah. Skor 2 dan 3 menunjukkan 
Fitrawanti et al.

Jurnal Ilmu Produksi dan Teknologi Hasil Peternakan 9 (2): 55-63

Tabel 1. Responden penelitian dan tema kuesioner SSAFE (2020)

\begin{tabular}{|c|c|c|}
\hline No & Tema kuesioner pada piranti SSAFE & Responden \\
\hline 1 & Kompleksitas melakukan food fraud pada bahan baku & Manajer kualitas dan keamanan pangan \\
\hline 2 & Ketersediaan teknologi melakukan food fraud pada bahan baku & \\
\hline 3 & Kemampuan mendeteksi cemaran bahan baku & \\
\hline 4 & Ketersediaan teknologi melakukan food fraud pada produk akhir & Manajer kualitas keamanan pangan \\
\hline 5 & Kemampuan mendeteksi cemaran pada produk akhir & \\
\hline 6 & Kompleksitas melakukan pemalsuan produk akhir & \\
\hline 7 & Kemampuan mendeteksi pemalsuan produk akhir & Manajer supply chain \\
\hline 8 & Deskripsi aktivitas proses produksi & \\
\hline 9 & Transparansi jaringan pasok & \\
\hline 10 & Insiden food fraud di bahan baku sejenis & Manajer kualitas dan keamanan Pangan \\
\hline 11 & Insiden food fraud di produk jadi & \\
\hline 12 & Pasokan dan harga bahan baku & Manajer supply chain \\
\hline 13 & Atribut khusus yang menentukan nilai bahan baku & Manajer procurement \\
\hline 14 & Kondisi ekonomi perusahaan & Manajer keuangan \\
\hline 15 & Strategi bisnis perusahaan & \\
\hline 16 & Budaya atau etika bisnis dari perusahaan & Kepala pabrik \\
\hline 17 & Insiden tindak pidana perusahaan di masa lampau & \\
\hline 18 & Tingkat korupsi negara & Berdasarkan literatur atau publikasi \\
\hline 19 & Gambaran tekanan keuangan perusahaan ke pemasok & Manajer keuangan \\
\hline 20 & Kondisi ekonomi pemasok & \\
\hline 21 & Bisnis strategi pemasok & Manajer procurement \\
\hline 22 & Budaya etika bisnis dari pemasok & \\
\hline 23 & Tindak kriminal dari pemasok & \\
\hline 24 & Viktimisasi pemasok & Manajer procurement \\
\hline 25 & Tingkat korupsi negara asal pemasok & \\
\hline 26 & Kondisi ekonomi pemasok & Manajer procurement \\
\hline 27 & Kredibilitas dari pemasok & Manajer procurement \\
\hline 28 & Etika bisnis industri susu dan rantai pasoknya & \\
\hline 29 & Tindakan fraud di industri sejenis & Manajer general secretary \\
\hline 30 & Tingkat kompetisi industri sejenis & \\
\hline 31 & Perbedaan harga bahan baku dan produk karena regulasi & Manajer procurement \\
\hline 32 & Pengawasan bahan baku & \\
\hline 33 & Verifikasi pengawasan food fraud di bahan baku & Manajer kualitas dan keamanan pangan \\
\hline 34 & Pengawasan food fraud di produk akhir & \\
\hline 35 & Verifikasi pengawasan food fraud produk akhir & \\
\hline 36 & Sistem informasi perusahaan terkait pengecekan stok & Manajer keuangan \\
\hline 37 & Sistem pelacakan dan penelusuran perusahaan & Manajer procurement \\
\hline 38 & Sistem seleksi integritas karyawan & Manajer personalia \\
\hline 39 & Pedoman etika bisnis perusahaan & Manajer General Secretary \\
\hline 40 & Kebijakan whistle blowing perusahaan & \\
\hline 41 & Persyaratan kontrak pemasok & Manajer procurement \\
\hline 42 & Sistem pengawasan fraud pada pemasok & \\
\hline 43 & Pengawasan sistem keseimbangan bahan baku pada pemasok & \\
\hline 44 & Sistem pelacakan dan penelusuran pada pemasok & Manajer kualitas dan keamanan pangan \\
\hline 45 & Pengawasan oleh sistem sosial & Manajer regulasi \\
\hline 46 & Efektifitas pengawasan food fraud di rantai pasok susu & Manajer General Secretary \\
\hline
\end{tabular}


kerentanan sedang dan rendah (Silvis et al. 2017). Hasil penghitungan digambarkan pada diagram radar faktor kerentanan kesempatan, motivasi dan pengawasan.

Analisis kedua adalah identifikasi faktor kerentanan lokal spesifik terhadap food fraud. Tahap ini dilakukan dengan mentabulasi jawaban responden dari kuesioner yang berisi pertanyaan terbuka. Jawaban yang tersedia, dicocokkan dengan pertanyaan di piranti SSAFE. Jawaban dikategorikan sebagai faktor lokal jika tidak terdapat di piranti SSAFE. Jawaban divalidasi terhadap sumber pustaka.

Penyusunan strategi mitigasi. Hasil analisis pemetaan gabungan dua perusahaan digunakan untuk menyusun strategi mitigasi yang dianalisis dengan piranti SSAFE. Strategi mitigasi merupakan hasil analisis keterkaitan antara faktor kesempatan dan motivasi dengan sistem pengawasannya. Finalisasi strategi mitigasi dilakukan dengan FGD (focussed group discussion) yang diikuti oleh pimpinan departemen di perusahaan.

\section{HASIL DAN PEMBAHASAN}

\section{Faktor Utama Kerentanan Food Fraud pada Susu Bubuk Berdasarkan SSAFE}

Faktor kesempatan. Hasil pemetaan gabungan faktor kesempatan PT X dan PT Y disajikan pada Gambar 1. Terdapat empat faktor utama yang mendukung food fraud yaitu kemudahan food fraud dilakukan pada jenis bahan baku tertentu (indikator 1), keberadaan teknologi melakukan food fraud pada bahan baku dan produk akhir (indikator 2 dan 4) serta bukti pernah terjadinya insiden food fraud (indikator 10 dan 11).

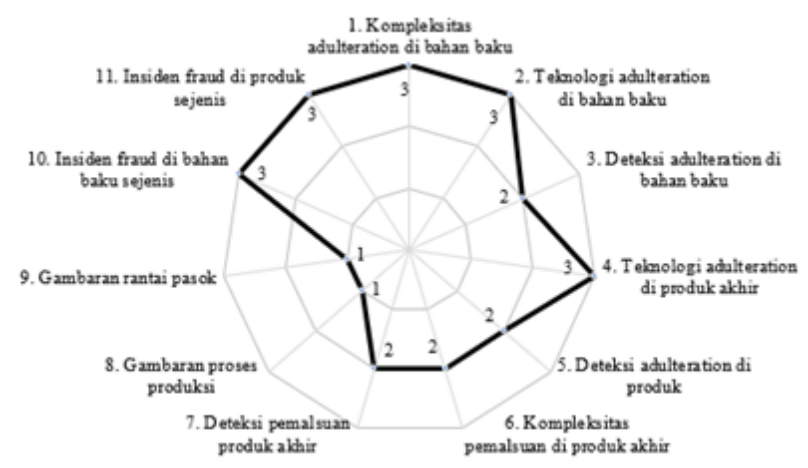

Gambar 1. Pemetaan gabungan faktor kesempatan pada kedua perusahaan

Kemudahan food fraud dilakukan pada bahan baku berkaitan dengan jenis bahan baku. Semakin mudah komposisi bahan baku diubah, kerentanan pada food fraud akan semakin tinggi. Bahan baku susu bubuk adalah susu cair dan bubuk susu yang rentan food fraud karena mudah dicampur dengan bahan kontaminan lain. Urutan tipe bahan baku dari yang mudah hingga sulit dilakukan food fraud adalah bahan cair, bubuk dan padat (SSAFE 2020).

Selain jenis bahan baku, food fraud terjadi karena adanya teknologi dan pengetahuan yang diketahui secara umum untuk melakukan food fraud. Semakin sederhana teknologi untuk melakukan food fraud pada produk atau bahan baku, semakin tinggi kerentanan produk untuk dicurangi. Teknologi food fraud pada susu cair umumnya adalah teknologi sederhana yaitu pengenceran, penggantian dan penambahan dengan bahan lain. Pengenceran dilakukan dengan menambah air untuk meningkatkan volume. Penggantian bahan contohnya penggunaan lemak nabati, tepung beras, glukosa, bubuk whey untuk meningkatkan kekentalan dan menjaga komposisi dari lemak, karbohidrat dan protein pada susu (Motta et al. 2014). Penambahan bahan lain pada susu antara lain hidrogen peroksida, sodium karbonat, bikarbonat dan urea digunakan untuk meningkatkan umur simpan (Afzal et al. 2011).

Kedua faktor di atas, didukung dengan adanya bukti insiden food fraud yang pernah terjadi pada susu dan turunannya. Di Brasil, prevalensi food fraud pada susu dan turunannya mencapai 38\% dibandingkan jenis pangan lain yaitu minyak sawit, minyak zaitun, daging, ikan, teh, dan kopi (Tibola et al. 2018). Analisis basis data United States Pharmacopeia (USP) dari tahun 1980 hingga 2010 menunjukkan susu termasuk pada 7 bahan baku yang memiliki laporan food fraud terbanyak (Moore et al. 2012). Insiden food fraud juga terjadi pada produk akhir. Insiden yang pernah dilaporkan antara lain penggantian tanggal kedaluwarsa, penggantian susu dengan tepung, dan pemalsuan produk susu (Decernis 2019).

Kedua perusahaan menunjukkan kerentanan rendah pada faktor kesempatan di aspek gambaran proses produksi dan transparansi rantai pasok (indikator 8 dan 9). Transparansi rantai pasok kedua perusahaan ditunjukkan dengan adanya kontrak pembelian bahan baku dan hubungan bisnis jangka panjang antara perusahaan dan pemasok. Ini terjadi karena terdapat transparansi syarat dan proses kualifikasi saat pemilihan pemasok bahan baku. Pada bahan baku susu cair, hubungan bisnis antara PT X dan peternak lokal berorientasi jangka panjang yaitu dengan pembinaan, transparansi spesifikasi bahan baku, dan penentuan harga beli berdasarkan kualitas bahan baku.

Sistem produksi di kedua perusahaan dilakukan dengan batch berkelanjutan selama 24 jam dan pengawasan fasilitas produksi dilakukan dengan penerapan sistem food defense. Hal ini menjadikan kedua perusahaan memiliki kerentanan rendah terhadap food fraud pada area produksi.

Faktor motivasi. Hasil pemetaan gabungan di faktor motivasi ditunjukkan pada Gambar 2. Pada kedua perusahaan, kerentanan tinggi faktor motivasi berasal dari eksternal perusahaan yakni tingkat korupsi negara tempat perusahaan berada (indikator 18), tingkat korupsi di negara asal bahan baku (indikator 25), dan perbedaan harga bahan baku dan produk di setiap negara karena regulasi yang berbeda (indikator 31).

Kedua perusahaan dalam studi kasus ini berlokasi di Indonesia yang memiliki peringkat ke-80 berdasarkan Corruption Perception Index tahun 2019 (Transparency 2019). Negara dengan peringkat lebih dari 76 dikategorikan sebagai negara yang memiliki tingkat korupsi tinggi (SSAFE 2020) dan perusahaan yang berlokasi di negara dengan 


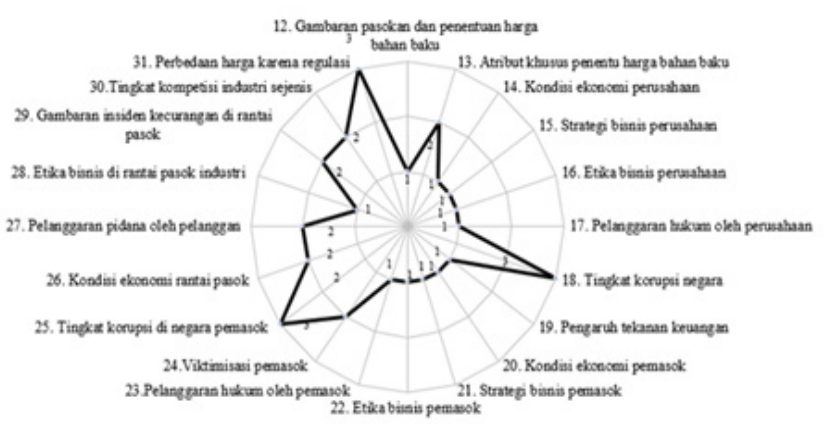

Gambar 2. Pemetaan gabungan faktor motivasi pada kedua perusahaan

tingkat korupsi tinggi memiliki risiko tinggi terhadap food fraud (Ruth et al. 2017).

Tingkat korupsi di negara asal bahan baku juga menentukan kerentanan pada food fraud. Bahan baku susu cair yang digunakan di PT X berasal dari pemasok lokal di Indonesia sehingga memiliki kerentanan tinggi terhadap food fraud. Negara dengan tingkat korupsi yang tinggi memiliki potensi food fraud karena lemahnya sistem pengawasan (USP 2016).

Faktor motivasi ketiga adalah perbedaan harga bahan baku dan produk susu di setiap negara karena regulasi yang berbeda (indikator 31). Bahan baku bubuk susu di PT X dan PT Y diimpor dari Amerika Serikat, Selandia Baru, Denmark, dan Australia. Harga bahan baku berbeda di setiap negara ditentukan oleh tipe pemeliharaan sapi, periode panen susu dan lokasi pemeliharaan (Tempesta \& Vecciato 2013). Selain itu, kebijakan biaya tarif impor juga berpengaruh. Di Indonesia, 79\% bahan baku industri susu adalah bahan impor (Pusdatin 2018). Fluktuasi harga dari negara asal dan perubahan kebijakan pemerintah pada biaya tarif impor berpengaruh terhadap harga dan ketersediaan bahan baku. Harga bahan baku yang berubah menyebabkan produsen susu bubuk mencari alternatif sumber bahan baku dari negara lain. Kerentanan food fraud meningkat bila negara alternatif sumber bahan baku adalah negara yang rentan terhadap food fraud (contoh Brasil dan India).

Faktor sistem pengawasan. Hasil pemetaan faktor sistem pengawasan ditunjukkan pada Gambar 3. Sistem pengawasan terhadap food fraud dibagi menjadi tiga yaitu sistem pengawasan di internal perusahaan, asosiasi industri dan negara. Pada Gambar 3, indikator kerentanan lemahnya sistem pengawasan internal pada perusahaan ditunjukkan pada sistem deteksi food fraud pada penerimaan bahan baku (indikator 32), uji integritas pada karyawan (nomor 38) dan prosedur tanggap darurat terhadap food fraud (nomor 50). Sistem deteksi food fraud pada penerimaan bahan baku bubuk susu impor saat ini dilakukan dengan pengujian visual dan uji melamin. Penentuan melamin sebagai parameter uji didasarkan pada insiden yang pernah terjadi di bahan baku susu. Deteksi dengan parameter uji yang lain belum dilakukan karena kesulitan menentukan parameter uji yang menjadi indikator terjadinya food fraud di susu bubuk.

Kerentanan sistem pengawasan pada asosiasi industri disebabkan karena belum terdapat integrasi antar perusahaan di rantai pasok industri susu bubuk untuk melakukan pengawasan food fraud (indikator nomor 45) dan tidak terdapat pedoman mitigasi food fraud (indikator nomor 46). Masing-masing perusahaan susu bubuk menerapkan sistem pengawasan food fraud pada rantai pasoknya berdasarkan pada kebijakan internal perusahaan.

Pada sistem pengawasan negara, kebijakan food fraud yang belum selaras dengan peraturan internasional (indikator nomor 47) dan penegakan hukum yang belum efektif pada kasus food fraud (indikator nomor 48) merupakan faktor pendukung kerentanan food fraud pada tingkat negara. Di Indonesia, saat ini sudah terdapat regulasi yang mengatur food fraud yaitu UU No. 18 tahun 2012 tentang Pangan pada pasal 71, pasal 89 dan pasal 90; UU No. 8 tahun 1999 tentang Perlindungan Konsumen pada pasal 4 dan pasal 7; dan Peraturan KBPOM No. 31 tahun 2018 yaitu terkait Label Pangan Olahan. Regulasi ini harus diselaraskan dengan aturan internasional yaitu CODEX. Saat ini pembahasan food fraud di CODEX baru di tahap perumusan definisi food fraud, food integrity, food adulteration (Spink et al. 2019) sehingga penyelarasan regulasi belum dapat dilakukan.

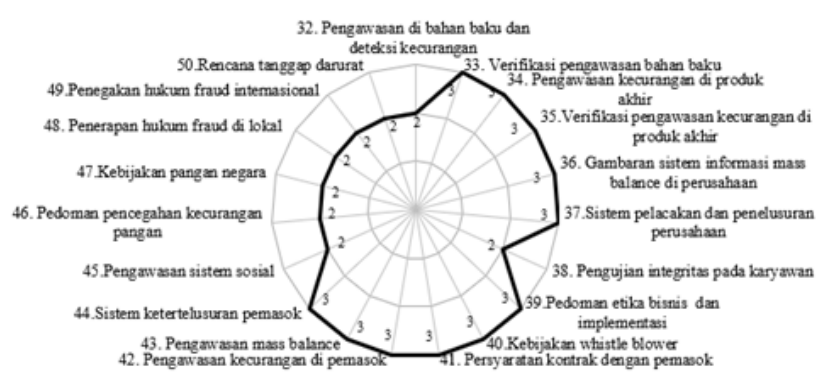

Gambar 3. Pemetaan gabungan faktor sistem pengawasan pada kedua perusahaan

Penegakan hukum terkait food fraud diatur dalam UU No. 8 tahun 1999 tentang Perlindungan Konsumen pada pasal 60 hingga 63. Sanksi yang diterapkan berupa sanksi administratif, pidana, denda dan hukuman tambahan bagi pelaku usaha. Meski sudah terdapat penerapan sanksi yang tegas, diperlukan langkah pencegahan terhadap food fraud dengan melakukan sistem pengawasan post market yang mempertimbangkan risiko food fraud. Kriteria yang menjadi pertimbangan risiko antara lain pemilihan kategori pangan yang berisiko kesehatan tinggi, pangan yang dikonsumsi dengan jumlah besar, pertimbangan keluhan konsumen dan kasus insiden food fraud yang pernah terjadi sebelumnya (Tibolla et al. 2018).

\section{Faktor Lokal Kerentanan Food Fraud}

Hasil wawancara dengan pertanyaan terbuka pada responden, mengidentifikasi beberapa faktor lokal spesifik yang relevan pada kerentanan food fraud di industri susu bubuk yaitu :

Penerapan standar produksi dan higinitas di peternak lokal yang belum memadai. Mayoritas peternak pada penelitian ini merupakan peternakan tradisional. Penanganan susu cair yang tidak sesuai dengan standar kebersihan dapat 
menurunkan kualitas susu. Rendahnya kualitas susu cair dapat mendorong peternak menambahkan bahan yang lain ke dalam susu untuk mempertahankan kualitasnya misalnya hidrogen peroksida, sodium karbonat, bikarbonat dan urea yang digunakan untuk meningkatkan umur simpan (Afzal et al. 2011).

Pandemi COVID-19 yang berdampak pada ketersediaan bahan baku. Saat penelitian ini dilakukan, di dunia dilanda pandemik Covid-19. Beberapa negara memberlakukan karantina wilayah yang mengakibatkan terjadinya pembatasan kegiatan impor dan ekspor yang berpengaruh pada stabilitas ketersediaan bahan baku bubuk susu impor (GAPMMI 2020). Kelangkaan bahan baku mendorong produsen susu mencari alternatif sumber bahan baku dari negara eksportir lain dan peternak lokal. Adanya pemasok baru berpotensi meningkatkan kerentanan terhadap food fraud.

Daya beli masyarakat Indonesia rendah. Daya beli masyarakat Indonesia rendah sehingga memiliki kecenderungan untuk mencari produk dengan harga terjangkau (Putri 2018). Hal ini berpengaruh pada penetuan harga produk akhir susu yang akan berimbas pada penentuan harga bahan baku. Supaya tetap diperoleh keuntungan ekonomi, produsen menetapkan harga bahan baku yang rendah. Rendahnya harga bahan baku akan mendorong pemasok melakukan kecurangan misalnya dengan penambahan bahan lain sehingga keuntungan ekonomi tetap diperoleh pemasok (Kamthania et al. 2014).

Sistem pengawasan sosial dari masyarakat yang masih rendah. Titik berat konsumen di Indonesia sebagian besar adalah pada harga produk yang murah. Kualitas dan keamanan pangan belum menjadi prioritas untuk kelas sosial menengah ke bawah (Putri 2018).

\section{Mitigasi Terhadap Faktor Kerentanan Utama Food Fraud}

Mitigasi terhadap food fraud disusun berdasarkan hasil analisis pada piranti SSAFE dengan mengaitkan antara faktor kerentanan kesempatan dan faktor motivasi dengan sistem pengawasan yang diterapkan di internal perusahaan, rantai pasok industri susu bubuk dan tingkat negara.
Mitigasi faktor kesempatan. Jenis bahan baku susu bubuk, adanya teknologi untuk melakukan food fraud dan bukti insiden yang pernah terjadi di produk dan bahan baku susu bubuk merupakan faktor kesempatan utama kerentanan food fraud di industri susu bubuk. Mitigasi faktor kesempatan dilakukan dengan penerapan sistem pengawasan internal perusahaan di tahap penerimaan bahan baku, produk akhir, sistem ketertelusuran dan evaluasi mass balance pada bahan baku dan produk akhir.

Pada Gambar 4, perbaikan sistem pengawasan internal perusahaan perlu dilakukan pada tahap penerimaan bahan baku terutama bahan baku bubuk susu impor. Saat ini, pemeriksaan pada bahan baku bubuk susu impor dilakukan secara visual dengan memastikan keutuhan dan kesesuaian segel kontainer saat kedatangan bahan baku. Pengujian cemaran, sebagai contoh melamine dilakukan setiap semester. Berbeda dengan bahan baku susu cair, pengujian untuk mendeteksi food fraud dilakuan pada setiap penerimaan dan akan menentukan status keberterimaan bahan baku. Tindakan mitigasi untuk memperkuat pengawasan pada penerimaan bahan baku bubuk susu yaitu dengan melakukan pengujian zat gizi dan cemaran pada bahan baku dari masing-masing pemasok secara rutin. Ini bertujuan untuk memperoleh profil bahan baku sebagai referensi karakteristik bahan baku dari masingmasing pemasok. Hal ini sesuai dengan strategi deteksi food fraud oleh USP (2016) yaitu dengan menguji keaslian dan karakteristik produk bukan mendeteksi bahan pencemar yang seharusnya tidak ada di dalam produk.

Mitigasi pada faktor motivasi. Kerentanan faktor motivasi untuk melakukan food fraud muncul dari internal perusahaan, pemasok dan rantai pasok industri susu. Kerentanan utama faktor motivasi internal perusahaan adalah kedua perusahaan beroperasi di negara Indonesia yang dikategorikan negara dengan tingkat korupsi tinggi (Tranparency 2019). Strategi mitigasi yaitu dengan menerapkan sistem pengawasan manajerial antara lain kebijakan whistle blower, adanya pedoman etika dan bisnis perusahaan dan pengujian integritas karyawan (Ruth et al. 2017). Pada Gambar 5, sistem pengawasan yang perlu dilakukan perbaikan adalah pada pengujian integritas

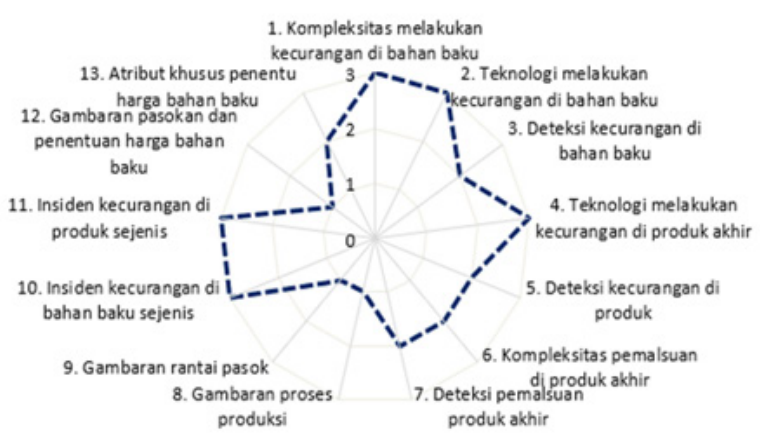

(a)

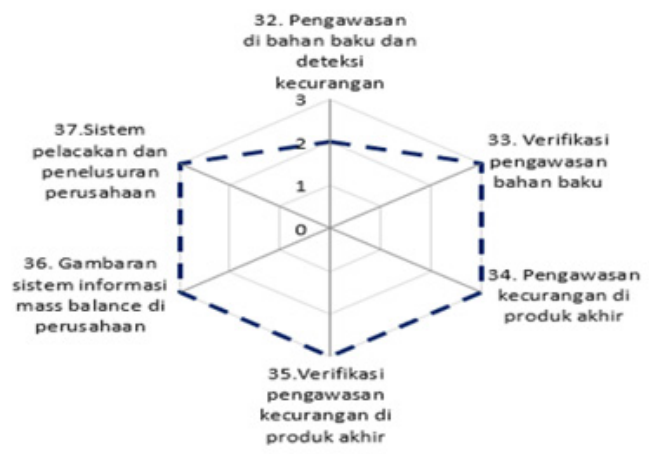

(b)

Gambar 4. Pemetaan faktor kesempatan (a) dan sistem pengawasannya (b) 


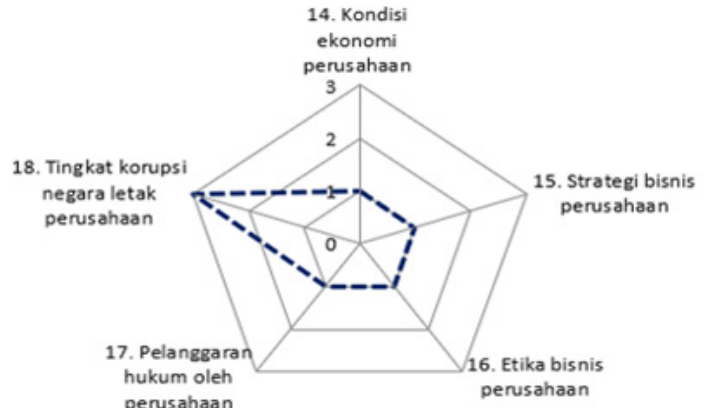

(a)

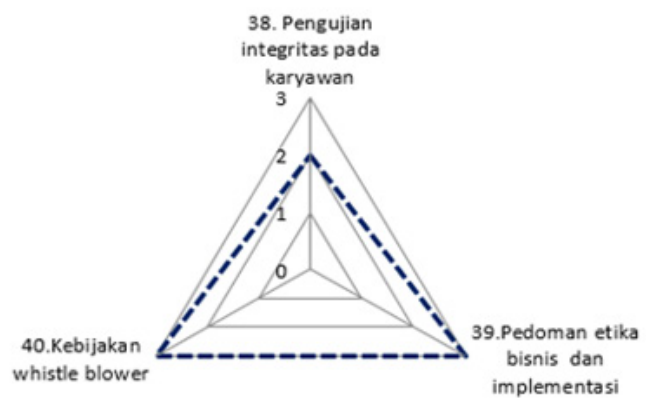

(b)

Gambar 5. Pemetaan faktor motivasi dari internal perusahaan (a) dan sistem pengawasannya (b)

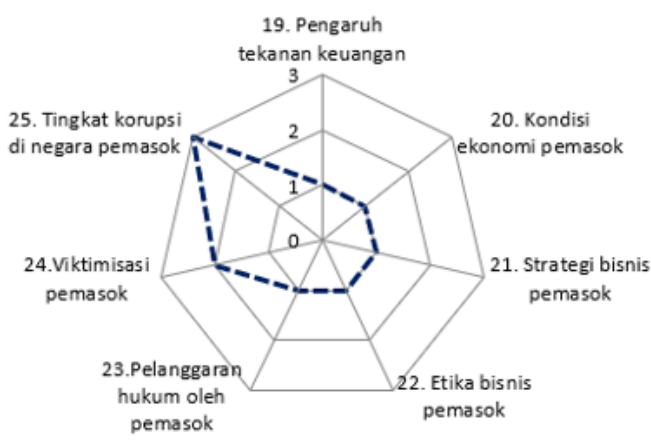

(a)

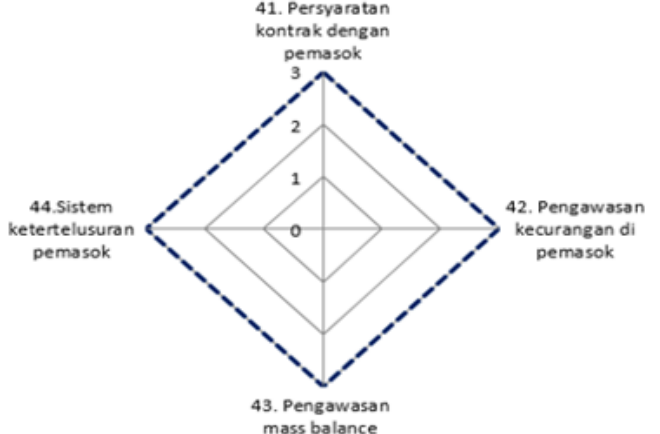

(b)

Gambar 6. Pemetaan faktor kesempatan (a) dan sistem pengawasannya (b)

karyawan. Penerapan pengujian integritas karyawan saat ini masih terbatas pada jabatan tertentu. Tindakan perbaikan perlu dilakukan dengan menerapkan pengujian integritas secara keseluruhan saat perekrutan karyawan.

Faktor motivasi dari pemasok berdasarkan Gambar 6 adalah pada negara pemasok bahan baku. Indonesia sebagai negara asal pemasok bahan baku susu cair dikategorikan sebagai negara dengan tingkat korupsi tinggi sehingga rentan pada terjadinya kecurangan. Mitigasi yang diterapkan untuk mencegah hal ini adalah dengan sistem pengawasan di pemasok (Gambar 6b). Saat ini, beberapa sistem pengawasan pemasok berjalan dengan baik ditunjukkan dengan skor 3 sehingga tidak diperlukan perbaikan tindakan mitigasi.

Faktor motivasi di rantai pasok yang menjadi kerentanan utama pada food fraud yaitu perbedaan harga bahan baku dan produk akhir antar negara karena perbedaan regulasi tarif impor dan harga bahan baku dari negara asal pemasok. Bahan baku susu bubuk di Indonesia mayoritas adalah bahan baku impor sehingga rentan pada perbedaan harga antar negara. Strategi mitigasi dilakuan dengan memperkuat sistem pengawasan di rantai pasok susu bubuk

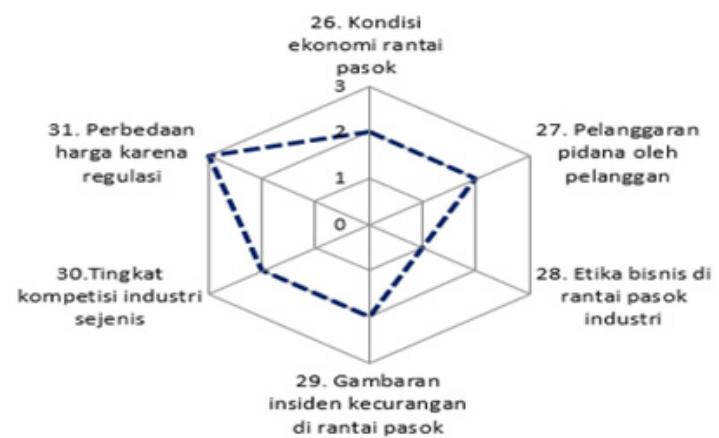

(a)

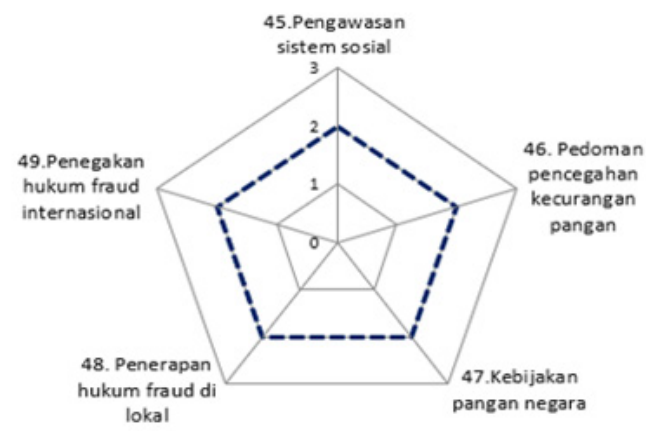

(b)

Gambar 7. Pemetaan faktor motivasi di rantai pasok industri susu (a) dan sistem pengawasannya (b) 
oleh negara dan asosiasi industri. Salah satu usulan mitigasi adalah penyusunan pedoman teknis yang berisi contoh praktik pencegahan food fraud yang dapat digunakan sebagai standar oleh industri.

Mitigasi faktor lokal. Penerapan standar produksi dan higienitas belum memadai di tingkat peternak. Strategi mitigasi yaitu dengan pembinaan terhadap peternak secara konsisten meliputi praktik higienitas, standardisasi kandang ternak, praktik cara pengolahan susu cair sebelum dikumpulkan ke KUD, serta peningkatan kepedulian masyarakat terkait risiko kecurangan pangan dengan edukasi yang dicantumkan di kemasan produk. Ini berupa himbauan kepada konsumen untuk memeriksa dengan cermat integritas kemasan, kondisi seal, kode produksi, kenampakan produk yang meliputi warna, bau, dan rasa ketika melakukan pembelian produk susu.

\section{KESIMPULAN}

Indikator utama kerentanan food fraud di faktor kesempatan adalah jenis bahan baku, adanya teknologi melakukan kecurangan dan bukti insiden yang pernah terjadi. Faktor motivasi terdiri dari tingkat korupsi negara di lokasi perusahaan, tingkat korupsi negara asal bahan baku dan perbedaan regulasi antar negara yang berpengaruh pada perbedaan harga. Sementara itu, kurangnya pengawasan pada penerimaan bahan baku, belum adanya uji integritas karyawan dan pedoman pencegahan food fraud dari pemerintah merupakan kelemahan di faktor sistem pengawasan yang meningkatkan kerentanan terhadap kecurangan pangan. Strategi mitigasi yang diusulkan adalah perbaikan di sistem pengawasan penerimaan bahan baku, penerapan uji integritas secara keseluruhan saat perekrutan karyawan, serta penyusunan pedoman teknis praktik pencegahan food fraud sebagai standar di industri.

\section{DAFTAR PUSTAKA}

Afzal, A., M. S. Mahmood, I. Hussain, \& M. Akhtar. 2011. Adulteration and microbiological quality of milk (A Review). Pakistan Journal of Nutrition. 10(12):11951202.

Daud A. R. U. S. Putro, \& M. H. Basri. 2015. Risks in Milk Supply Chain: A Preliminary Analysis on Smallholder Dairy Production. Livestock Research for Rural Development. 27(7):137.

Decernis. 2019. Food fraud database in milk powder 2009 - 2019. https://decernis.com/solutions/food-frauddatabase/[19 Mei 2020].

Everstine, K., J. Spink, \& S. Kennedy. 2013. Economically Motivated Adulteration (EMA) of Food: common characteristics of EMA incidents. J Food Prot. 76(4):723-735.

Fung, F., H. S. Wang, \& S. Menon. 2018. Food safety in 21st century. Biomed J. 41:88-95.

GAPMMI (Gabungan Pengusaha Makanan dan Minuman Seluruh Indonesia). 2020. Daya Tahan Industri Pangan dalam Menghadapi Pandemi COVID-19. http://www.gapmmi.id/article/read/7640/ daya-tahan-industri-pangan-dalam-menghadapipandemi-covid-19 [1 Juli 2020].

GFSI (Global Food Safety Initiative). 2014. GFSI position on mitigating the public health risk of food fraud : GFSI paper. https://mygfsi.com/press releases/ gfsi-position-paper-on-mitigating-the-public-healthrisk-of-food-fraud/[9 September 2019].

Kamthania, M., J. Saxena, K. Saxena, \& D. K. Sharma. 2014. Milk Adultration: Methods of Detection \&Remedial Measures. International Journal of Engineering and Technical Research. :15-20.

Market Research. 2019. Indonesia baby food global data 28 October 2019. https://www.marketresearch.com/ GlobalData-v3648/Indonesia-Baby-Food-12817071/[5 Juni 2020].

Moore, C. J., J. Spink, \& M. Lipp. 2012. Development and application of database of food ingredient fraud and economically motivated adulteration from 1980 to 2010. J Food Sci.77(4):118-126.

Motta, C., T. M., R. B. Hoff, F. Barreto, R. B. S. Andrade, D. M. Lorenzini, L. Z. Meneghini, T. M. Pizzolato. 2014. Detection and confirmation of milk adulteration with cheese whey using proteomiclike sample preparation and liquid chromatographyelectrospray-tandem mass spectrometry analysis. Talanta.120:498-505.

Pusdatin (Pusat Data dan Sistem Informasi Pertanian Sekretariat Jendral Kementerian Pertanian). 2018. Outlook 2018: Komoditas Pertanian Subsektor Peternakan Susu. http://epublikasi.setjen.pertanian. go.id/arsip-outlook/70-outlook-peternakan/627outlook-susu-2018 [9 October 2020].

Putri, A. S. 2018. Challenge to enforce food Safety law and regulation in Indonesia. In: Book of Abstract. IOP Conference Series: Earth and Environmental Science 175 International Conference of Industrial Technology for Sustainable Development.IOP Publishing, Sydney. https://iopscience.iop.org/ article/10.1088/1755-1315/175/1/012216/pdf [6 Oktober 2020].

Silvis, I. C. J., S. M. Van Ruth, H. J. van der Fels-Kerx, \& P. A. Luning. 2017. Assesment of food fraud vulnerability in the spices chain: an explorative study. Food Control. 81:80-87.

SSAFE (Safe Supply Affordable Food Everywhere). 2015. SSAFE Food fraud Vulnerability Assesment Tools. https://www.ssafe-food.org/our-projects/\#[6 Oktober 2020].

Spink, J., \& D. C. Moyer. 2011. Defining the public health threat of food fraud. J. Food Sci. 76(9):R157-R163.

Spink, J., P. V. Hegarty, N. D. Fortin, C. T. Elliott, \& D. C. Moyer. 2019. The application of public policy theory to the emerging food fraud risk:next steps (review). Trends Food Sci Technol. 85:116-128.

Tempesta, T., \& D. Vecchiato. 2013. An analysis of the territorial factors affecting milk purchase in Italy. Food Qual Prefer. 27(1):35-43.

Tibola, S. C., S. A. da Silva, A. A Dossa, \& D. I. Patricio. 2018. Economically motivated food fraud and 
adulteration in Brazil: incidents and alternatives to minimize occurrence. J Food Sci. 83(8):2028-2038.

TI (Transparency International). 2019. Corruption Perception Index 2019. https://images.transparencycdn. org/images/2019_CPI_Report_EN.pdf [6 Oktober 2020]

USP (United States Pharmacopeia). 2016. Food fraud mitigation guidance Appendix XVII.https://www.usp. org/sites/default/files/usp/document/our-work/Foods/ food-fraud-mitigation-guidance.pdf [6 October 2020].
Van Ruth, M. S., W. Huisman, \& P. A. Luning. 2017. Food fraud vulnerability and its key factors. Trends Food Sci Technol. 67:70-75.

Yang, Y., W. Huisman, K. Hettinga, N. Liu, J. M. L. Heck, G. H. Schrijver, L. Gaiardoni, \& S. M. Van Ruth. 2019. Fraud vulnerability in the Dutch milk supply chain: Assesment of farmers, processors and retailers. Food Control. 95:308-317. 